DOI: $10.22363 / 2312-8127-2018-10-1-70-78$

\title{
CHINA - EGYPT BILATERAL RELATIONS UNDER MUBARAK (1981-2011)
}

\author{
E.A. Bazanova, A.A. Kudelin \\ Peoples' Friendship University of Russia \\ 6 Miklukho-Maklaya St., Moscow, 117198, Russia
}

\section{E.I. Semenova}

\author{
National Research University «Higher School of Economics» \\ 17 Malaya Ordynka St., bldg. 1, Moscow, 119017, Russia
}

The article aims to investigate the main features of China-Egypt bilateral relations in period of Hosni Mubarak ruling in Egypt, to follow up the character of relations and mutual impact.

The period has a great value for investigation of the steps to partnership, how two countries cooperated in new conditions on the world arena. Hosni Mubarak had risen in power in 1981, it also was a period, when Deng Xiaoping was pursuing a policy of "open doors". Mubarak built friendly relations with China, when whole world was facing rising of New China with new agenda and enormous potential. In 1990s China became the net-exporter of the oil because of increasing demand of energy sources. Relations between two countries are complex and facing certain challenges. Considering China and Egypt impact on the third world, these cases are known to be a success story of development in unique way, pursued by the eastern countries, that's why specialists in economy and political development always speak about Chinese and Egyptian ways of development in modern world, so this kind of cooperation is interesting from that point of view.

So called Arab spring has put an end of Mubarak era and this period became a crisis for China economic and political strategy of cooperation with Egypt. Therefore, the authors pretend to consider Mubarak - China relations period in whole as a historical stage.

Keywords: China-Egypt relations, economic and political cooperation, Mubarak era, Arab Spring

Introduction. The article aims to investigate the main features of ChinaEgypt bilateral relations in period of Hosni Mubarak ruling in Egypt, to follow up the character of relations and mutual impact. The period has a great value for investigation of the steps to partnership, how two countries cooperated in new conditions on the world arena. Relationships between two countries began in 1953 with commercial sense, with offer of Egypt to buy Egyptian cotton. After three years in 
1956 two countries established official conditions for diplomatic dialogue, the core of relations still was trading. Egypt became the first African-Arab country, which recognized the Communist China. That period of time China was seeking any international support, nevertheless Egypt was also considered as an important strategic point due to its territorial position, the Suez canal, two seas, dividing Europe and Africa etc. 1956 for Egypt was a year of demonstrating power and independence from France, firstly, by nationalization of the Suez Canal, which lead to Suez crisis, secondly, by establishing relationships with Communist China. The second historical step of China-Egypt cooperation before Mubarak was marked with signing the technical and economic cooperation agreement, it used to be renewed every year since 1964. During the period Sadat was a president of Egypt, China funded the brick factory in Egypt [7. P. 95].

Research. The PRC government sought to establish relations with the Arab states of the Middle East. During the Bandung Conference (April 1955) first premier of the People's Republic of China Zhou Enlai invited Gamal Abdel Nasser, the president of Egypt, to visit China.

In May 1955 Egyptian delegation visited China and signed an agreement on cultural cooperation. In this period Egypt was the key partner of China in the Middle East. After several visits of Egyptian journalists and artists in 1955-1956 the government of Egypt officially recognized the Communist government of China. After that several agreements on trade and economic cooperation were signed and China became the third importer of Egyptian cotton in the world. Chinese government aimed to improve and maintain the relations with Egypt as the leader of Arabic world so it decided to support Arabic countries in all international issues such as Palestinian problem and Suez Canal nationalization. In the period from 1950's until the early 1970s the country's policy in the Middle East region had "Pro-Arab" character and it played an important role in developing relations with Egypt.

In 1970's China's policy in Middle East was determined by the conflict with USSR. At the same time Anwar Sadat, the next president of Egypt, who came to power after the death of Nasser, also spoiled relations with USSR and was searching for the new vector of Egyptian foreign policy. Leaders of PRC in their speeches were blaming USSR for inciting Arab-Israeli conflict. In those circumstances Anwar Sadat became the closest ally of China in the region. Thus, it can be concluded that until the 1980s the relations between China and Egypt were determined mostly by the ideological component.

The 1980s became for China not only a period of considerable internal political changes, but also the time of revision foreign policy interests, in particular, rethinking the PRC strategy in the Middle East. Sino-Egyptian cooperation has acquired a new impetus for development based on the cooperation, expansion of economic and trade relations and interaction in the field of culture, education and the media. Middle Eastern policy of China reflected the desire of Chinese government to create a peaceful environment in the region for implementation of economic cooperation with Arab states [11. P. 91]. 
Hosni Mubarak became a first Egypt president who visited the People Republic of China. He was on the seat since 1981 to 2011. The first time in 1976 Mubarak visited China, he was a vice-president of Egypt. Thereafter he personally met Mao Zedong, Deng Xiaoping, Jiang Zemin, Zhou Enlai, Hu Jintao.

In the articles dedicated China-Egypt relations authors as rule underline the common conditions faced by two countries such as need to safeguard sovereignty, to enhance foreign trade. Two countries considered as two successful case of development on the East, China and Egypt assumed a responsibility to support developing countries.

Hosni Mubarak contributed a lot in China-Egypt bilateral relationships, after his first visit in China in 1976, he named Chinese people as brother of Egyptians [6. P. 20]. He claimed that cooperation could provide a development of economy, trade and agriculture. In 1983 Mubarak as a new president of Egypt had an official meeting with Deng Xiaoping. During the meeting, both leaders underline the importance of cooperation, proclaimed eternal friendship between nations. In September 1983, the International Commission of Jurists awarded him a peace prize. Mubarak attached importance of developing friendly relations with China, he visited China many times. In April 1994, after receiving the invitation of Chinese President Jiang Zemin, Mubarak visited China for the sixth time.

The seventh visit of Hosni Mubarak to China is known to be of great value for bilateral relations of two countries. It was a step of establishing strategic cooperation towards the $21^{\text {st }}$ century [1]. In 1999, the then heads of the two states Hosni Mubarak and Jiang Zemin signed a communiqué on the establishment of SinoEgyptian strategic cooperation.

They stressed that it was important for the two influential developing countries of China and Egypt to work together for greater solidarity and closer cooperation among developing countries, to seize a gap between developed and developing worlds.

Main points of the communiqué are following:

1) estimating cooperation between countries as healthy, friendly and stable;

2) China supported the right of Palestinian people to self-determination and their own land;

3) Uniting against terrorism;

4) Accepting the idea of leaders annual meeting;

5) Together support developing countries to reduce gap with developed countries.

Since the 2000s, even before the concept was included in the course of party policy, the PRC began to use the principle of "soft power" in relations with developing countries and, in particular, with Arab states of the Middle East. One of the main directions of this principle in practice was the cooperation of the PRC with Arab countries in the field of education. Egypt became the key partner in the region in educational cooperation. In 1996 first joint scientific symposium was organized in Beijing. As a result ministers of education of the both countries formed joint working group with the aim to maintain cooperation between Ministries of China 
and Egypt in the field of scientific and cultural exchange. Subsequently several cultural and educational events were organized in China and Egypt. November 17 1997 in Cairo representatives of two countries signed in an agreement about mutual recognition of diplomas of several Chinese and Egyptian universities. The list of Chinese universities included Beijing University, Beijing Institute of Foreign languages, Beijing University of language and culture, Shanghai pedagogical University, Yunnan University and others. Among Egyptian universities there were Cairo university, Alexandria University, Ain Shams university, Zagazig University, Minnia University. One of the biggest centers of Chinese studies in the Middle East was opened in Ain Shams university. On the faculty of foreign languages al-Alsun of this university there is an oldest chair of Chinese languages which was opened in 1958. As a result of intensive cooperation in educational field Egypt became the center for training of specialists in Chinese languages, philology and researches in the Middle East. At the same time most of the Chinese students and teachers preferred to go to Egyptian universities for summer schools and practices to improve their Arabic languages such as Cairo university, al-Ahar university, $6^{\text {th }}$ October University, Nahda University [12. P. 87].

During Mubarak era China and Egypt significantly improved cooperation in tourism. After signing an agreement on tourism developing between China and Egypt in October 2001 number of Chinese tourists visiting Egypt was constantly growing. In 200535000 Chinese tourists visited Egypt.

The most important strategic point in relations became an agreement of building new port Sokhna. It was signed in a framework of joint communiqué in Beijing. Two sides set up strategic cooperation relations for the 21 st century, so as to push bilateral relations to a new stage of development. Sokhna port was planned to build in the Suez Economic Zone, which would provide Chinese companies an access to the world's principal maritime routes [5]. So Chinese companies would have a relatively short distance to reach ports on both the northern, southern, and eastern Mediterranean borders, and they will have reduced the distance to North American consumer markets approximately by half [7. P. 95]. It is known to be a turning point of cooperation nature between two countries, from export-import relations to investment and joint projects, from traditional form to modern. One of the significant beginning was the cooperation in the Suez Economic Zone North-west Gulf, in addition to establishing the Egyptian companies' affiliates in China [8]. To frame it all the China-Africa Development Fund was founded. To sum the results of Mubarak's efforts in developing China-Egypt cooperation up, the 1999 was truly fruitful year. Along with the development of Suez Economic Zone Chinese companies started to invest in Egyptian communication market. For a long time British and French companies Vodafone and France Telecom were leaders in Middle Eastern communication sector however during 2000s Chinese company Huawei started to gain the shares in this market. It was attractive for consumers because of the low price and rich experience in providing Internet and mobile connection in inaccessible and underdeveloped areas, accumulated during laying communications in the western 
provinces of the PRC. This allowed specialists to solve problems on realization of telecommunication projects, installation of $2 \mathrm{G}$ and $3 \mathrm{G}$ equipment and wireless Internet in deserted regions far from the major megacities that especially relevant for countries such as Egypt. During Mubarak era Chinese companies started to invest in Egyptian automotive industry as well. In 2006 Chery Automobile together with Egyptian Aboul Fotouh Group started to produce Chery car with the trade mark Speranza. As part of the upgrade of the Cairo taxi park, the Egyptian government since 2009 began a massive replacement of the old cars for cars Speranza. By that time Egypt became one of the largest recipients of foreign direct investment from China in Africa and Middle East. Egypt was one of five African countries where China participated in free economic zones developing. In 2000s many Chinese companies invested in Egyptian textile industry and production of fertilizers. The largest investment project of China in Egypt was drilling company Sino-Tharwa (Sino-Tharwa Drilling Company), a joint venture organized by the largest state oil corporation Sinopec and Egyptian state Tharwa Petroleum Company. Based on the foregoing, we can conclude that during the reign of Mubarak, Egypt and China reached an unprecedented level of cooperation in the economic sphere and Egypt became one of the main objects of Chinese investment in the Middle East [11. P. 92].

In political sphere Egypt acted as one of the initiators of the establishment of the Forum on Sino-Arab cooperation in 2004. At the end of January President $\mathrm{Hu}$ Jintao proposed Mubarak to pay a state visit to Egypt and received a warm reception. He held in-depth talks with Mubarak on bilateral relations, the situation in the Middle East and the international situation, and reached broad consensus. During the visit, he went to the headquarters of the League of Arab States (Arab League), and met with the Arab League Secretary General Amr Moussa.

On the same day, the Chinese Foreign Minister issued a communique with the Secretary-General of the Arab League to announce the establishment of the China-Arab Cooperation Forum. This visit not only made new contributions to the further development of Sino-Egyptian relations, but also marked a new stage of milestone significance between China and the Arab League.

In October 2006, the Xinhua News Agency cited Hosni Mubarak's statement: "Egypt does not consider China just a friendly country, it sees him as a brother" [1]. Thus, Egypt began to acquire the characteristics of a Chinese outpost in cooperation with Africa and the Arab world.

Turning now to the question of cooperation forms, China's investors prefer to make bilateral agreements with the government to bypass market forces of tender and competition. China is acting through state-owned enterprises such as CNOOC, PetroChina and ICBC. In April 2004, the Ministry of Commerce authorized CNOOCSINOPEC United International Trading to import crude oil; CNPC, Sinopec, Sinochem and Zhuhai Zhenrong had been the only companies importing crude [10].

China's non-economical tools represented by generating strategies, conceptions, image, which are called 'soft power'. The most significant China's conception might be represented by quote from majority of Party leader's speeches like 
"China is a developing country, all developing countries unite! We help you develop out of rules generated by Washington consensus world". For all intents and purposes, it is a very valid method, from the beginning China makes an opposite to Western countries, metropolises in the past.

China's leaders underline every time they don't have any political interest in the country, against intervention and respect ruling structure and nation rights. China easy accommodates to the expectations and preferences of ruling elites, provide money and support either for international or internal needs. China is known to be an attractive partner even more than USA. China is ready to overpay $20-30 \%$ for guarantee keeping positions [4].

Occasionally, China suffered from drought in January, 2011. These circumstances forced China bought wheat in international market, meanwhile Egypt was the major wheat supplier. But Egypt was in crisis provoked by Arab Spring and China did not consider it as a stable partner that time. By that China was a trigger of the Arab Spring crisis in Egypt's economy [2]. Subsequent events in the Middle East showed that China suffered losses of its investment projects and most probably changed the priorities in the Middle East from Egypt to Gulf countries. As a result Egyptian economy suffered losses as well and until the Egyptian government is able to prove the stability of its regime Chinese companies unlikely are going to return to Egyptian market. If we talk about political cooperation Mubarak era was the period of stability and predictability in Egypt which contributed to developing of long term relations with such a strategic partners as China. And it will take a long time for a new government to prove their ability to recover the trust and loyalty of Chinese partners.

Conclusion. Historical points of China-Egypt relations demonstrate the mutual interests of both sides. Taking into consideration Chinese interest, Egypt was a strategic aim, which could be characterized as "window for Chinese economic and political influence in the MENA region". For Egypt, China became a tool of independent from the West and important commercial partner, which would help with economic development in Egypt. The world trade community always considered China as a place of big opportunities to import in obvious circumstances of population. Sino-Egyptian relations have a long history and stable, Mubarak contributed this stability in very fruitful way.

Mubarak said about China: "Every time I came to China, I received a sincere and friendly reception, which reflects the very good relationship between us and the continuous development" [9]. The end of Mubarak era, brought with the Arab Spring became a crisis for China economic and political strategy of cooperation with Egypt. Therefore, the authors pretend to consider Mubarak - China relations period in whole as a historical stage.

(C) E.A. Bazanova, A.A. Kudelin, E.I. Semenova, 2018 


\section{REFERENCES}

[1] An Huihou. ZhongAi Shounao Waijiaode chenggongdianfan cong Mubalake Zongtong diqici Fanghua Tanqi [Successful model of China-Egypt Cooperation after Mubarak's $7^{\text {th }}$ visit to China]. [In Chinise]. URL: http://www.ixueshu.com/document/ a1cdebe596257df1.html

[2] Assem Reda Abu Hatab, Nada Abdelhamed, Shoumann Huo Xuexi. Exploring EgyptChina bilateral trade: dynamics and prospects. Journal of Economic Studies. 2012. Vol. 39. Iss. 3. Pp. 314-326.

[3] Assem Reda Abu Hatab, Romstad Eirik. Competitiveness analysis of Egyptian cotton exports with special focus on the Chinese market. China Agricultural Economic Review. 2014. Vol. 6. Iss. 2. Pp. 248-263.

[4] Brandt Loren, Rawski G. Thomas. China's Great Transformation. Cambridge: Cambridge University Press, 2008.

[5] Bräutigam Deborah, Tang Xiaoyang. African Shenzhen: China's special economic zones in Africa. The Journal of Modern African Studies. 2011. Vol. 49. Pp. 27-54.

[6] Elshamy Hany. The economic determinants of Chinese foreign direct investment in Egypt. Journal of Chinese Economic and Foreign Trade Studies. 2015. Vol. 8. Iss. 1. Pp. 20-26.

[7] Gadallah Yasser M. An Analysis of the Evolution of Sino-Egyptian Economic Relations. In book: Toward Well-Oiled Relations? China's Presence in the Middle East Following the Arab Spring. Ed. by Horesh N. London: Palgrave Macmillan, 2016. Pp. 94-115.

[8] Law № 83 of 2002 on Economic Zones of a Special Nature // Official Web Site of the Suez Canal Authority. URL: http://hrlibrary.umn.edu/research/Egypt/Special\%20Economic\%20Zones\%20Law\%20No_\%2083\%20of\%202002.pdf.

[9] Mubarak and China. Embassy of the People's Republic of China in the Arab Republic of Egypt (Official web-site). URL: http://www.fmprc.gov.cn/ce/ceegy/chn/ajgk/333333/.

[10] Zhongguo dui Alabozhichunde huiying yuelaiyue chengshu [China's reaction on Arab Spring]. [In chinise]. Qingniancankao, April 2012, http://qnck.cyol.com/html/2012-04/11/ nw.D110000qnck_20120411_2-02.htm.

[11] Bazanova E. Osnovnye etapy sotrudnichestva KNR s arabskimi stranami Blizhnego Vostoka v 1980-2010 gg. [Main Stages of Cooperation between China and the Arab States of the Middle East in 1980-2010]. [In russian]. Bulletin of Peoples' friendship University of Russia. Series World History. 2011. № 4. P. 84-93.

[12] Bazanova E. Strategiya myagkoi sily KNR po sotrudnichestvu s arabskimi stranamu Blizhnego Vostoka v oblasti obrazovaniya 1990-2010 gg. [China’s Soft Power Strategy in the Cooperation with Arab Countries of Middle East in Educational Field in 1990-2010]. [In russian]. Vestnik MGOU. Seria Istoriya i Politicheskie nauki. 2011. № 2. P. 85-90. 


\title{
КИТАЙСКО-ЕГИПЕТСКИЕ ОТНОШЕНИЯ В ЭПОХУ МУБАРАКА (1981-2011)
}

\author{
Е.А. Базанова, А.А. Куделин \\ Российский университет дружбы народов \\ ул. Миклухо-Маклая, 6, Москва, Россия, 117198 \\ Е.И. Семенова \\ Национальный исследовательский университет \\ «Высшая школа экономики» \\ Малая Ордынка ул., 17, стр. 1, Москва, Россия, 119017
}

Цель статьи - исследовать основные особенности китайско-египетских отношений в период правления Хосни Мубарака в Египте с тем, чтобы определить характер этих отношений и взаимное влияние рассматриваемых стран.

Данный период имеет большое значение с точки зрения развития партнерства и взаимодействия двух стран на мировой арене. Хосни Мубарак пребывал у власти в течение 30 лет. Он пришел к власти в 1981 г., в то же время, когда Дэн Сяопин провозгласил политику «открытых дверей» в Китае. Мубарак выстроил дружественные отношения с Китаем тогда, когда весь мир настороженно наблюдал за подъемом Китая как нового игрока на мировой арене с огромным потенциалом. В 90-е гг. Китай стал нетто-экспортером нефти в связи с растущими потребностями, связанными с экономическим ростом. Отношения между двумя странами развивались в разных сферах и подверглись различным испытаниям. В частности, одним из вызовов стало состязание между США и Китаем за влияние на Египет и регион Ближнего Востока в целом.

Обсуждая влияние Китая и Египта на страны «третьего мира», следует отметить, что обе эти страны представляют собой пример успешного развития по своему уникальному пути. В связи с этим экономисты и политологи часто упоминают «китайский» и «египетский» путь развития в современном мире. Таким образом, сотрудничество Китая и Египта представляет интерес и в этом аспекте, как сотрудничество двух стран с разными политическими и экономическими системами.

С началом «Арабской весны» эра Мубарака в Египте подошла к концу. Это вызвало кризис китайской стратегии экономического и политического сотрудничества с Египтом. Несмотря на это, авторы склонны считать эру Мубарака важным этапом в китайско-египетских отношениях.

Ключевые слова: китайско-египетские отношения, экономическое и политическое сотрудничество, эпоха Мубарака, «Арабская весна»

\section{Информация об авторах / Information about the authors}

Базанова Елена Алексеевна - кандидат исторических наук, ассистент кафедры всеобщей истории Российского университета дружбы народов. E-mail: ealeenab@gmail.com 
Куделин Андрей Александрович - кандидат исторических наук, старший преподаватель кафедры всеобщей истории Российского университета дружбы народов. E-mail: andkudelin@mail.ru

Семенова Елизавета Иссаевна - тьютор Школы востоковедения факультета мировой экономики и мировой политики Национального исследовательского университета «Высшая школа экономики».E-mail: elissemenova@gmail.com

Elena Bazanova - PhD in History, Lecturer of the Department of World History, Faculty of Humanities and Social Sciences, Peoples' Friendship University of Russia. E-mail: ealeenab@gmail.com

Andrey Kudelin - PhD in History, Senior Lecturer of the Department of World History, Faculty of Humanities and Social Sciences, Peoples' Friendship University of Russia. E-mail: andkudelin@mail.ru

Elisaveta Semenova - Lecturer of School of Asian Studies, National Research University Higher School of Economics. E-mail: elissemenova@gmail.com

\section{Для циитирования / For citations}

Базанова Е.А., Куделин А.А., Семенова Е.И. Китайско-египетские отношения в эпоху Мубарака (1981-2011) / Вестник Российского университета дружбы народов. Серия: ВСЕОБЩАЯ ИСТОРИЯ. 2018. ТОМ 10. № 1. С. 70-78. DOI: 10.22363/2312-8127-201810-1-70-78.

Bazanova E.A., Kudelin A.A., Semenova E.I. China - Egypt bilateral relations under Mubarak (1981-2011) / RUDN JOURNAL OF WORLD HISTORY. 2018. 10(1): 70-78. DOI: 10.22363/2312-8127-2018-10-1-70-78.

Рукопись поступила в редакцию / Article received: 07.09.2017 